\title{
Article
}

\section{The ICSID Tribunals in Deciding International Investment Corruption Cases: Possible Solutions*}

Hongwu Yin ${ }^{* *}$

Corruption issues have attracted increasing attention in international investment law studies and practice in recent years. When confronted with the corruption defenses invoked mainly by host states, some ICSID tribunals decided to decline the jurisdiction. However, part of the arbitral jurisprudence has aroused strong criticism. ICSID tribunals are legitimately supposed to exercise the jurisdiction and are lawfully obliged to investigate the nature of corrupt activities, and strike the balance of interests between the disputing parties. It is preferable to strengthen the collaborative interaction between ICSID and the domestic anti-corruption enforcement authorities to combat international investment corruption. The existing treaties (or specific treaty provisions) to combat corruption in international business transactions and the requirement for international cooperation, as well as domestic anti-corruption enforcement legislation, have laid a solid legal foundation for the establishment of such an anti-corruption coordinative mechanism between the ICSID and domestic corruption regulatory authorities on a global level.

Keywords: Corruption Defense, ICSID, Balancing Approach, International Anti-Corruption Coordinative Mechanism

* This article is supported by 2018 Hunan Provincial Innovative and Open Project 'AAbuse of Process' in International Investment Arbitration and the Regulation"(18K022); 2019 Hunan Provincial Social Science Union Project "Innovation of the BITs Between China and African Countries under BRI" (XSP19YBZ178); Changsha Judicial Bureau "Foreign Legal Services Research Program"(2019); Construction Program of the First-Class Discipline in Hunan Normal University.

** Associate professor of International Law at Hunan Normal University, PRC. A.B. (Hunan U. Sci. \& Tech.), A.M. (Zhejiang), Ph.D. (Hunan Normal U.). ORCID: https://orcid.org/0000-0002-55907510. The author may be contacted at: lawschool2014@163.com/Address: Law School of Hunan Normal University, 36\# Lushan Road, Yuelu District, Changsha Hunan Province, PRC.

All the websites cited in this article were last visited on July 30, 2020. 


\section{INTRODUCTION}

Corruption is becoming an increasing challenge for international investment activities partly because many investments are intended for developing countries, which have pre-mature legal systems and high probabilities of corruption. Recently, the corruption issue has received greater significance both in theory and practice of international investment law. Specific ICSID arbitral jurisprudence indicates that the increasing awareness regarding the adverse effects of corruption should not be overlooked. ${ }^{1}$

Corruption is unable to be controlled effectively by the national dimension alone. Over the past two decades, numerous international conventions have been enacted to manage corruption problems including the United Nations Convention against Corruption (2005). By adhering to these anti-corruption conventions, the contracting countries recognize that corruption is a widespread phenomenon in international economic operations, which is morally and legally unacceptable. Increasing awareness regarding the adverse effects of corruption on the global economy has rendered corruption a highly controversial issue in international investment arbitrations.

The primary purpose of this research is to present the realistic difficulties which are confronted by ICSID tribunals in handling the corruption defenses raised mainly by the host states. The present paper seeks to address these problems by encouraging tribunals to exercise jurisdiction and adopt balancing approach in deciding the merits of the disputes. A coordinative mechanism between domestic anti-corruption enforcement authorities and ICSID tribunals is strongly proposed.

\section{ICSID Tribunal in the Corruption Defense of The Host State}

\section{A. Corruption Defense Invoked by the Host State}

To date, the corruption defense ${ }^{2}$ invoked by the host state in investment arbitration proceedings has developed into an adversarial strategy aimed at frustrating the various claims by foreign investors. Because the investment arbitration tribunals are increasingly inclined to confirm the corruption defense raised by the host state, 
more respondent countries are relying on it as a favorable arbitral skill. After the $S G S$ v. Pakistan case, ${ }^{3}$ some typical international investment arbitration cases arose in which the host state invoked the corruption defense, e.g., World Duty Free v. Kenya case, Fraport AG Frankfurt Airport Services Worldwide v. The Republic of the Philippines case, Inceysa Vallisoletana S.L. v. Republic of El Salvador case, Metal-Tech Ltd. v. Republic of Uzbekistan case, and MOL v. Republic of Croatia case. In these cases, given that the host state's corruption assertion had been testified, ${ }^{4}$ all ICSID tribunals approved the corruption defense against foreign investors by the host states and decided the cases where tribunals were lacking in jurisdiction over the investment disputes, with the investors' claims being dismissed.

\section{B. ICSID Tribunal's Declining of Jurisdiction over Corrupt International Investment Cases}

\section{1. "Corrupt Investment" Violates Fundamental Principles of Law}

Foreign investment undertaken within the host state territory must both substantively and procedurally comply with the fundamental principles of law. In the corruption defense cases, the tribunals considered that investments procured through corruption were contrary to the international public policy, so that they had no competence to handle the investment claim.

The tribunal for the Inceysa v. El Salvador case held that both the SpainSalvador Bilateral Investment Treaty (BIT) and the ICSID Convention are international treaties whose interpretation is based on Article 42(1) of the ICSID Convention. The tribunal decided that Inceysa could not resort to ICSID arbitration according to the general principles of law as good faith, Nemo auditur propriam turpitudinem allegans, international public policy, and unjust enrichment. ${ }^{5}$

In the World Duty Free v. Kenya case, the tribunal concluded itself lacking in jurisdiction because both disputing parties chose English law as the applicable law to settle the dispute based on Article 42(1) of the ICSID Convention. ${ }^{6}$ The tribunal further stated that the investor's bribery was against "most (if not all) international public policy of the country," thereby conflicting with the transnational public policy. ${ }^{7}$ Although narrower in scope than international public policy, transnational public policy is also widely used given the principle includes "fundamental natural law rules, principles of universal justice, jus cogens [norms of] ... international 
law, and the general principles of morality accepted by ... 'civilized nations.","

\section{2. "Corrupt Investment" and the "In Accordance" Provision in International Investment Agreements}

The BIT generally stipulates that the investment should be made "in accordance with the host state's laws (and regulations)." Therefore, any illegally-made investment is excluded from the domain of "qualified investment" based on the host state's domestic laws. As corruption is an illegal activity within nearly all internal law order worldwide, the foreign investment's compliance with the host state's laws is relevant to the jurisdiction of the investment arbitral tribunal. ${ }^{10}$

In several ICSID investment arbitration cases, the tribunal eventually declined its own jurisdiction and dismissed the investor arbitration claims under the jurisprudence that the specific investment did not comply with the "in accordance" requirement asked by the investment treaties, so that the investment concerned was categorized into an unlawful one and should be excluded from protection by the investment treaty. ${ }^{11}$ Taking the Inceysa v. El Salvador case as an example, the tribunal decided that the Salvador government's consent to the ICSID jurisdiction agreed in its BIT (1995) with Spain could not be extended to the fraudulently-made investment because it violated Salvador laws and, therefore, was unqualified. The tribunal consequently refused to exercise jurisdiction over the arbitration case. ${ }^{12}$

\section{ICSID Tribunals' Current Difficulties in Handling Host State's Corruption Defense}

ICSID tribunals take prudential considerations of the host state's (the respondent) corruption defense invoked in international investment cases and correspondingly make decisions to decline their own jurisdiction over certain cases. However, such parts of the final award normally constitute the most controversial issues in international investment arbitration cases (mainly ICSID arbitration cases) involving the corruption defense. The arbitral jurisprudence of ICSID tribunals regarding their lack of jurisdiction over corruption-involved investment disputes is subject to strong criticism. Therefore, previous studies have challenged or questioned the currently prevalent arbitral jurisprudence. ${ }^{13}$ Some western scholars 
have stated that "for a very long period in investment arbitration, tribunals have been myopic if not ignorant vis-à-vis allegation of corruption." ${ }^{14}$

\title{
A. ICSID Tribunal's Declining Jurisdiction over Corrupt Investment and Infringing Procedural Justice
}

When deciding the foreign investment dispute cases involving corruption (or other unlawful activities) defenses, the ICSID tribunal in Metal-Tech Ltd. would state:

\begin{abstract}
given the corruption of investment is against the host state laws, the investment creation does not abide by the host state laws, hence the investment does not fall within the category of protected investment, which is defined in Article 25 ICSID Convention or specific BITs; therefore, no agreement is reached on the consent to investment arbitration between foreign investors and the host state, and the final decision regarding the tribunal's lack of jurisdiction is concluded. ${ }^{15}$
\end{abstract}

Whenever a tribunal testifies its own jurisdiction, it cannot escape from making a preliminary judgment on such issues as whether the investment is qualified and the arbitration agreement exists because BITs usually provide "in accordance with host state laws" stipulations. However, tribunals tend to make 'hasty' decisions that certain foreign investment should be excluded from the scope of BITs protection because investment activities are involved with corruption. Thus, they concluded that no arbitration agreements exist between foreign investors and the host state. ${ }^{16}$ Nevertheless, as the entire reasoning process is seemingly "rough, rush-to-conclusions and defective," it is hard to say the award was rendered in compliance with the spirit of procedural justice. The criteria of investment were first proposed by the tribunal in the Fedax $v$. Venezuela case and further elaborated on by other arbitral tribunals, among which the five-factors standard initiated by the tribunal in the Salini v. Morocco case gained popular recognition, namely: (1) a certain duration period; (2) regularity of profit and return; (3) assumption of risks; (4) substantial commitment; and (5) significance for the development of the host state. ${ }^{17}$

It is easy to determine that the "in accordance with the host state laws" requirement does not constitute the objective factor to evaluate a 'qualified' investment. Special attention must be given to the reality that many of China's BITs that have been settled in recent years excluded the "in accordance" element 
from the investment definition provision. Taking the China-Germany BIT as an example, although the "in accordance" factor explicitly required defining the investment in the 1983 version, ${ }^{18}$ the revised one (2003) does not include such a requirement. ${ }^{19}$ The 2004 China-Uganda BIT stipulates the same type of investment definition provision as in the 2003 China-Germany BIT. ${ }^{20}$

Moreover, tribunals drop the critical issue of corruption at an early stage, avoiding the tricky business of delving into the details of the greasing process because some important substantive issues that are supposed to be clarified during the fact-finding process have been rashly decided at the preliminary jurisdictional stage without conducting a substantive examination. Thus, it is inadequate to safeguard the procedural rights of foreign investor claimants (e.g., court appearance and cross-examination, as well as submission of the evidence and argument making), factually going against the procedural justice, and eventually deviating from the original aim and purpose for establishing the investor-state dispute settlement mechanism because investment arbitration is essentially designed for the protection of private investors.

\section{B. Applying the "In Accordance" Provision in Investment Arbitration Practice}

As for the prevalent arbitral reasoning of the present investment tribunals, one question may arise: Is such reasoning generally convincing? There arise three uncertainties when interpreting and applying the "in accordance" provisions in investment treaties. The first is which laws and regulations within the territory of the host state must a foreign investor abide by and what amounts to in accordance criterion? Must a prospective investor conduct a full legal-compliance audit for every investment, ensuring that it "complies with each provision of domestic law?" This could make the "in accordance" provision an "Achilles heel of investment arbitration" because any violation of domestic law could conclude that the investment does not meet the "in accordance" requirement, so that the host state's corruption defense would be successfully invoked. Such interpretation entails great uncertainty and the specific purpose of the ICSID mechanism as well as the BITs to provide foreign investment with effective protection become frustrating. ${ }^{21}$

The second uncertainty lies in determining whether the "in accordance" provisions impose a continuous obligation on the investor to monitor the compliance 
of an investment or whether such provisions only apply to the initiation period of the investment. The tribunal for the Fraport case suggested that "in accordance" provisions only applied to the initiation of an investment and subsequent violations of the host state's law "might be a defense to claimed substantive violations of the BIT, but could not deprive the tribunal acting under the authority of the BIT of its jurisdiction." ${ }^{22}$ In practice, however, the investment tribunals have not reached consensus on the investment time of applying the "in accordance" provisions.

The final uncertainty involves whether such mitigating factors exist as might excuse the violations of the applicable law. The tribunal for the Fraport case hypothesized that an investor who breaks the law might still be allowed to bring a claim if one of several factors is present, which include a good-faith mistake by the investor regarding an unclear host-state law, reliance on incorrect legal advice, or a violation "not central to the profitability of the investment, such that the investor might have made the investment in ways that accorded with local law without any loss of projected profitability." 23 Moreover, an investor could potentially assert an affirmative defense of "estoppels" to block the corruption defense if the host state endorsed the investment, while "knowingly overlooking" the investor's conduct not in compliance with its laws. ${ }^{24}$ To date, although no tribunal has yet invoked estoppels ${ }^{25}$ or any of the above mitigating factors (so they remain only hypotheticals) when confronted with the corruption defense, tribunals are naturally responsible for a comprehensive consideration of all these factors as well as the estoppels principle.

\section{Preliminary Declining of Jurisdiction by ICSID Tribunals and Substantial Unbalancing of Interests between Disputing Parties}

When faced with a host state's corruption defense, some ICSID tribunals have refused to exercise their jurisdiction to protect the public interest. The arbitral tribunal states that international public policy aims to keep the public away from harmful misbehaviors such as bribery. ${ }^{26}$ Given that corruption goes against international public policy, investment tribunals treat it as a naturally disposed principle to: (1) enforce the contract involved with the corruption element; and (2) provide investment treaty protection to the related investment because it has been tainted by corruption. ${ }^{27}$ Hence, ICSID tribunals prefer to give unfavorable awards to punish those foreign investors who have engaged in corrupt activities. ${ }^{28}$ 
However, these decisions have not truly protect the public. On the contrary, the awards function is encouragement for the corrupt misconduct of the host state officials. According to the awards, even though the host state violated its treaty obligation of investment protection, it is almost impossible to pursue its potential legal responsibilities because the tribunals decline to exercise jurisdiction over the investment disputes. Thus, the corrupt officials in the host state do not have to worry about (let alone be afraid of) their past corrupt misconducts because even if they have committed corruption misbehaviors, their "unjust enrichment" remains untouched under the present ICSID arbitral jurisprudence. For example, the Kenyan government under Daniel arap Moi-noting the facts underlying the World Duty Free case-made the collection of bribes a national sport and require anyone who wants to make a substantial investment in that country pay hefty bribes. ${ }^{29}$ Why should such a government, for which bribery is a major business, be rewarded for its graft?

The declining of ICSID tribunals' jurisdiction over investment disputes involved with corruption will only incur unfavorable consequences for foreign investors. Unlike the host state, foreign investors are obliged to rely on international investment arbitral proceedings to protect their interests and rights. Pursuant to Article 27(1) of the ICSID Convention, ${ }^{30}$ once investors have chosen international arbitration to settle investment disputes between them and the host states, the back road accessible to home state's diplomatic protection is blocked and arbitration becomes almost the only approach to obtain a fair adjudication. Although the wrongful corruption of investors are subject to legal punishment, the investors need not be the only ones to endure the negative results of the wrongful acts.

As the other disputing party, the host state is in a different situation usually resorting to public power to fulfill its value-pursuit and self-interest protection rather than relying on international arbitration. The host state has accepted the foreign investment before tribunals refuse to exercise their jurisdiction over the disputes. With the final decision made, the host state is suspicious of gaining unjust enrichment. ${ }^{31}$

Based on the tribunal's current prevailing arbitral jurisprudence, the investment contract should be treated as void because corruption infringed the public order. In practice, the host state has probably expropriated the investors' assets instead. ${ }^{32}$ 
Where the tribunals decline to exercise the jurisdiction, the foreign investors' assertions have no place to be claimed. Thus, the tribunals' arbitral jurisprudence did not take any prudential consideration of the ancient principle "unjust enrichment" in civil law. ${ }^{33}$ By recognizing the corruption defense raised by those states whose officials solicit bribes, future ICSID tribunals would 'unfairly' permit corrupt host states to reap the rewards of their own misconduct.

Thus, ICSID tribunals have permitted host states to invoke corruption defenses and refuse to exercise jurisdiction over disputes whenever an investor commits bribery to win a government contract. In doing so, the tribunals can achieve the original purpose to protect the public interests, while the respondent host states (even the officials) "can evade any potential liability for investment violations and obligation of compensation and factually profit from the violation of international investment law", ${ }^{34}$ and the respondent's gaining of unjust advantages on one side results in an imbalance between foreign investors and the host state. In conclusion, "Against the Laws, Lose All" on the part of foreign investors is manifestly unfair from the perspective of weighing up the rights and obligations between foreign investors and the host state.

\section{Tribunal's Congenital Inadequate Power in Investigating Corruption}

The arbitral award was later found to be incorrect such as in the 2007 Siemens $A G$ case. $^{35}$ It reveals the 'ruthless' reality that investment tribunals lack adequate instruments and techniques to pursue anti-corruption criminal investigations. Traditionally, arbitration (including investment arbitration) was not perceived as an ideal venue for deciding claims of bribery or corruption. The questioning of or even resistance to the arbitrability of corruption-related claims in international investment arbitration proceedings was based on a limited view of the investment tribunals' jurisdiction. It covered concerns about the tribunals' restricted power to compel the production of evidence and the tribunals lack the authority to impose criminal penalties. ${ }^{36}$

Although it is undeniable that investment tribunals are facing some realistic difficulties, this does not necessarily mean that the investment tribunals should not or are unable to engage in combating corruption in international investment activities. Tribunals have enough leeway and leverage to settle investment disputes and eventually conclude a fair and just result. Certain anti-corruption functions 
overlap between ICSID and domestic enforcement authorities.

Therefore, on the condition that an anti-corruption coordinative legal framework could be established successfully between these two types of anticorruption organs, the effectiveness of an international corruption combating campaign will be guaranteed. Meanwhile, once the global public interest in international investment law is practically protected, the goal of constructing a "clean and beautiful", international investment community is not far from being fulfilled.

\section{Possible Solutions to the Difficulties in the ICSID InVestment Arbitrations}

When ICSID tribunals are confronted with the difficulties dealing with the corruption defenses usually invoked by host states, the investment arbitral tribunals are recommended to improve the corrupt investment arbitration practice. The following suggestions are proposed. First, ICSID tribunals should commit themselves to exercise jurisdiction over the case and probe into the nature of corruption activities. Second, ICSID tribunals should adopt the balancing approach to weigh up the rights and interests between the disputing parties. Third, ICSID tribunals should strengthen their collaboration and interaction with the domestic anti-corruption authorities to combat international investment corruption. Thus, a coordinative framework is strongly proposed to be constructed between ICSID and domestic anti-corruption enforcement authorities.

\section{A. ICSID Tribunals' Jurisdiction over Investment Disputes and the Nature of Corrupt Activities}

As for the host state's corruption defense, tribunals should assume the quasijudicial responsibility of deciding the merits of the investment disputes instead of discarding its legally-empowered abilities and functions. Hence, one of the continuing missions that is unavoidable for tribunals to fulfill in the jurisdictionexercising stage is to probe into the nature of specific corruption activities and adopt a balancing approach to measure the interests and obligations between foreign investors and the host state 


\section{Unilateral Corruption Activity or Bilateral Corruption Activity?}

Unilateral corruption involves corrupt activities on the part of only one party. It means fraud on the part of the investor in international investment arbitration. In practice, corruption such as bribery usually involves illegal activities by two parties, i.e., the foreign investor's bribe-offering and the host state official's bribe-taking. Based on this classification criteria, the Inceysa, Fraport, and Kardassopoulos cases can be categorized into one type of arbitration case and only the World Duty Free case involved common corruption activities on both sides. ${ }^{39}$ Investment tribunals permit the host state to invoke the corruption defense for the investor's unilateral corruption activity.

\section{Hard Corruption or Soft Corruption?}

Corruption may be either 'hard' or 'soft.' Hard corruption refers to the offer or promise of an undue or improper advantage to a public official. ${ }^{40}$ This may be done directly or through an intermediary. It entails an intentional act pursued to influence a public official in the performance of his/her official duties that, in turn, is directed at gaining an undue business advantage. Soft corruption (also called "influence peddling") is essentially an attenuated form of hard corruption. It entails the offer or promise of an undue advantage to a person who claims to be able to exert an undue influence on a public official. Influence peddling involves an intermediary. In contrast to hard corruption, however, the intermediary need not actually pay a bribe to the official who conducts the administrative duties. Moreover, a foreign investor engaging in influence peddling need not intend to influence the specific conduct on the part of the public official. Several ICSID tribunals have upheld the corruption defense in the cases of hard corruption, while no tribunal has allowed a state to invoke the defense merely for the reason of influence peddling. In this regard, historically, future tribunals will also hesitate to do so. ${ }^{41}$

\section{Contract Being the Object of Corruption or Contract Being Procured by Corruption?}

Corruption may be found in a contract's object or its procurement. Both produce a successful corruption defense. In the first case, the consideration (bribery) offered by one party is an illegal act and the contract is legally unenforceable. Such a 
contract is equivalent to a "contract for murder." ${ }^{42}$ Parties to the contract are unable to make good on committing bribery. However, it is the second situation that most ICSID tribunals encounter in practice, i.e., becoming involved in corruption by procuring a contract. For example, an overseas corporation commits fraud or bribery to win a public concession. While settling the investment dispute the tribunal has generally permitted states to invoke the corruption defense, even if the contract itself is free from defects. ${ }^{43}$

\section{Corruption Being a Minor Breach of Law or a Significant Contravention of Law?}

The tribunal for the Inceysa v. El Salvador case decided that the exemption of the host state's compensatory responsibilities should be based on the occasion where "an investment is made through a significant contravention of the applicable law, for example, by way of bad misrepresentation or fraud in the government bidding proceedings. ${ }^{44}$ Foreign investors invested under the protection of the BIT via its own fraudulent actions (including the forgery of various documents or the submission of false financial statements). Therefore, the involved investor should bear the full responsibilities for their illegal acts.

However, in the Tokios Tokelés case, although the form of corporation indicated in the name was slightly noncompliant with the regulatory requirement, there was no significant fraudulent act as the investor undertook in the Inceysa case. $^{45}$ Therefore, arbitral tribunals should make deliberate distinctions of the illegal actions based on their severity and never roughly categorize any investment involving an investor's unlawful activities into "unqualified investment" beyond the protection of international investment law. For those investments that are involved with only slight law-breaking misbehaviors, tribunals shall not decline jurisdiction over the investment disputes for the reason of corruption defense.

\section{B. The Balancing Approach of ICSID Tribunals}

All international investment disputes involving the corruption element have shown that an intertwined and interactive relationship exists between foreign investors and the host state. Whether the arbitration involves common misconducts or only illegal acts on one side, the balancing approach is expected to provide a more flexible solution to coordinating the rights and duties between both disputing 
parties having unequal social powers. ${ }^{46}$

A previous study showed that investment tribunals conduct a balancing test and make the final award based on the merits of the case. Such a regime would: (1) prevent the favoring of one party unfairly over the other; (2) make government officials cautious about engaging in corruption activity; and (3) encourage states to create and implement anti-corruption measures. ${ }^{47}$ In the World Duty Free case, for example, restitutio in integrum could not be employed for the return of a USD 2 million bribe that the investor had paid. What about the other expenses and assets that the WDF had invested, however? Concerning voidable agreements, restitutio in itegrum can put the parties back to the positions they would have been in had the contract not been performed. Thus, restitutio in integrum could act to unwind the contract and place both parties in their prior positions minus the USD 2 million bribe that was paid. A compromise is much fairer than what was seen in the World Duty Free case, in which the World Duty Free Co. (WDF) lost everything for committing a less serious illegal act. ${ }^{48}$

\section{Preconditions for Host States' Successful Corruption Defense}

Regarding the practical use of the balancing approach, a previous study suggested that the successful invocation of the corruption defense by the host state has imposed preconditions. ${ }^{49}$ To invoke the corruption defense, the host state should commit that it has implemented the anti-corruption rules as required by its legal framework or has adopted powerful countermeasures to combat corrupt criminal activities. $^{50}$ Torres-Fowler called on tribunals to adopt comparative fault rules and strongly proposed that the host state should invoke corruption defense only to the extent that it was free of guilt. ${ }^{51}$

\section{Host State's Liabilities for Official's Contribution to Corruption}

When examining the legality of the investment involving corruption, tribunals should explore the nature of the corrupt activities and decide the proportion of corruption liabilities for each party. As the tribunal for the MOL $v$. Republic of Croatia case insisted on taking a balancing consideration of both the state and foreign investor's wrongful actions, it did not approve the host state's corruption defense totally or unconditionally. ${ }^{52}$ Where the government officials performing the administrative duties become involved in the specific corruption, ICSID 
tribunals should handle the host state's misconduct simultaneously and prevent the host state from evading its legal responsibilities that it should assume based on the "attribution doctrine." adopted by investment tribunals of simply declining to exercise jurisdiction and dismissing the case rashly. ${ }^{54}$ Even if the investor's corruption has been verified during the arbitration proceeding, it is still irrational that the host state should benefit solely from all the interests of the foreign investment. ${ }^{55}$ Losco showed that the state would be held responsible for compensating the investor for a percentage of its claim corresponding to the percentage of the fault attributable to the state. Tribunals should take serious consideration of the damages caused by the pursuit of economic interest by investors for bribe-paying and realize that it is the usual voluntary bribe solicitation of high-ranking officials that seduces the corrupt doings of investors. Therefore, a foreign investor who seeks out and bribes a lowlevel official might only be able to recover 25 percent of their claim, whereas the host state in which high-level officials regularly extort bribes might be responsible for 75 percent of the investor's claim. ${ }^{56}$

In practice, if a certain foreign investment has obtained the market access permit granted by the host state administrative authorities in charge after the host state has implemented a "case-by-case" review and approval system for accepting foreign investments, the specific investment would be treated as having been made in compliance with the conditions required by the laws and regulations in the territory of the host state. In such cases, it is difficult for the involved host states to excuse themselves from the legal responsibilities that they are supposed to assume for "the conduct of any State organ shall be considered an act of that State under international law."

\section{A Proposal for Internationally Coordinative Mechanism between ICSID and Domestic Anti-corruption Enforcement Authorities}

Only through the coordination or communication between ICSID tribunals and domestic anti-corruption authorities responsible for international investment can it be ensured that neither the investor nor the host state reaps the rewards of its own corrupt behavior. ICSID arbitration may completely overlook covert corruption. The ICSID dispute settlement system is not designed to uncover covert corruption in the foreign investment context. In practice, covert corruption is likely to be 
far more common than the open bribery as seen in the World Duty Free case. ${ }^{57}$ The authorities tasked with investigating and enforcing domestic anti-corruption statutes are much more adept at discovering corruption with the Siemens $A G$ case proving this point. ${ }^{58}$

The Siemens $A G$ case reflects that it is completely necessary to establish a communicative and collaborative mechanism between ICSID tribunals and domestic anti-corruption authorities because of the lack of appellate procedures in ICSID arbitration. Moreover, an investigation by domestic anti-corruption authorities (a conviction, civil judgment, or prosecution agreement) may provide host states with an incentive to expropriate an investor's assets and excuse corrupt government officials from punishment, thereby leading to an unfair outcome. Therefore, it is strongly proposed to promote the interaction and counterbalance between the domestic anti-corruption mechanism and ICSID arbitration proceedings. ${ }^{59}$

\section{Legal Framework for the Establishment of a Coordinative Mechanism between ICSID and Domestic Anti-corruption Authorities}

The existing treaties (or specific treaty provisions) that aim to combat corruption in international business transactions call strongly for international cooperation. Meanwhile, the domestic anti-corruption enforcement legislation has laid solid legal foundations for global governance over international investment corruption. Therefore, the establishment of an international anti-corruption coordinative mechanism between ICSID and domestic corruption regulatory authorities is instrumentally guaranteed.

\section{Anti-corruption Instruments on an International Level}

The OECD Convention on Combating Bribery ${ }^{60}$ of Foreign Public Officials in International Business Transactions (1997), ${ }^{61}$ the Criminal Law Convention on Corruption of the Council of Europe (1999), and the United Nations Convention against Corruption (2003) are the forerunners in fighting corruption for international commercial transactions.

The USMCA Agreement (2018) emphasizes the relevance of collective countermeasures against corruption by the contracting states and the importance of anti-corruption cooperation and coordination with other international 
organizations. $^{62}$

\section{Domestic Legislation for Combating International Investment Corruption}

Given that international commercial corruption committed by foreign investors is an unfairly competitive activity usually seen in and jeopardizing to the host state's market economy, many countries (or regions) have enacted domestic legislation to govern this type of commercial misconduct. Taking America as an example, with the stipulation of laws and regulations such as the 1977 Foreign Corrupt Practices Act (FCPA), the Trade and Competitive Act (1988), and the International AntiBribery and Fair Competition Act (1998), a sizable, intricate, and comprehensive domestic legal framework targeted at combating overseas commercial corruption has been established.

To ensure the normal conduct of international criminal judicial assistance, the International Criminal Judicial Assistance Law of the People's Republic of China was promulgated and became effective on October 26, 2018. ${ }^{63}$ The law is enacted to "strengthen international cooperation in the field of criminal justice, effectively punish crime, protect the legitimate rights and interests of individuals and organizations, and safeguard national interests and social order. ${ }^{, 64}$ Because the law stipulates the collaborative mechanism between China and foreign countries (or international organizations such as ICSID) to ensure the normal conduct of international criminal judicial assistance, China undoubtedly becomes the forerunner in proposing a legally interactive mechanism between domestic anti-corruption authorities and the ICSID, which is designed to solve corruption problems by promoting justice and transparency on the global stage. ${ }^{65}$

\section{Interactive Strategies between ICSID Tribunals and Domestic Anti-corruption Authorities}

Situation One: ICSID Arbitration Preceding the Domestic Anti-corruption Investigation

As the Siemens case showed, when an arbitral award is issued before the commencement of the domestic anti-corruption investigation, ICSID tribunals can make incorrect conclusions because of the failure to determine the evidence of covert corruption. If the incorrect award has already been rendered and paid, domestic anti-corruption authorities should ask the involved foreign investor to waive or 
disgorge the award.

- Waiver of Unlawful Rights or Disgorgement of Unjust Compensation Gained by Previously-made Defective ICSID Awards

The ICSID tribunal found that Argentine's actions over the course of the crisis constituted a "creeping" expropriation and ordered Argentine to compensate Siemens in the amount of USD 217 million. ${ }^{66}$ Shortly after the tribunal issued its award, however, "German prosecutors discovered Siemens had engaged in rather astonishing acts of systematic bribery around the world. ${ }^{, 67}$ Following its FCPA settlement in 2008, Siemens waived its right to the USD 217 million award that it had won against Argentine. Although it is unclear why Siemens did so, its forfeiture of the award is a normatively desirable result. If the ICSID tribunal had been aware of Siemens' corruption facts, it would have approved a corruption defense in favor of Argentine. Alternatively, had the investigation by German prosecutors never occurred, Siemens would have succeeded in reaping the benefits of its own corrupt conduct by exploiting the dispute-resolution provisions in a treaty whose protections was not entitled to enjoy. ${ }^{68}$ Accordingly, to ensure the correct outcomes in the future, domestic anti-corruption authorities should require that investors waive their rights to ICSID awards as a condition of prosecution agreements. In conformity with the maxim of restitutio in integrum, the claimant's waiver of an award restores the parties to the position they would have enjoyed had the respondent host state succeeded in asserting the corruption defense. ${ }^{69}$

When a respondent host state has already paid the specific compensation rendered in an award, the 'disgorged' payment might be used as follows: (i) forfeited to the investigating country's government; (ii) implement changes to the reporting and bookkeeping practices within the claimant corporation; or (iii) placed into an anti-corruption fund to support anti-corruption efforts in the host state. Alternatively, the investor could return the funds to the host state, but doing so would achieve the same result as if the tribunal had recognized the host state's corruption defense. ${ }^{70}$ However, this would essentially permit the host state as the sole subject to reap the benefits of its corrupt conduct where the officials are involved in corruption (e.g., bribe-taking). The best solution might incorporate several of these elements, based on the subsequent domestic prosecuting authorities' best judgment 
in the given circumstances aimed at achieving the most just result. ${ }^{71}$

- The Amount Foreign Investors Lost in ICSID Arbitration and Subsequent Domestic Anti-corruption Penalties

Supposing that the ICSID tribunal has made an unfavorable award against corrupt foreign investors before domestic anti-corruption authorities have initiated a commercial corruption investigation, can the final monetary penalties imposed by the domestic anti-corruption authorities be offset by the number of economic losses foreign investors suffered in the anterior ICSID arbitration? Some commentators say "yes." Among these, Bhojwani proposes that "domestic anti-corruption penalties be offset by the amount an investor loses in arbitration." 72 This proposal entails decreasing the violator's corruption penalty by the amount of its failed ICSID claim if the host state invokes the corruption defense. This proposal is attractive because it seeks to reduce the price paid by corrupt investors so that the combined effect of domestic anti-corruption enforcement and the corruption defense successfully invoked in the investment arbitration do not act as a deterrent to foreign direct investment. ${ }^{73}$

However, a different argument against offsetting rests on the assumption that the offsetting "could potentially undermine the FCPA's supply-side approach to corruption. Both parties to mutual corruption are culpable, and capitulating to investors could do more harm than good by weakening the appearance of certainty attached to FCPA sanctions." ${ }^{74}$ Such concerns could be greatly relieved for at least two reasons. First, ICSID tribunals are strongly proposed to adopt the balancing approach to provide a more flexible solution to coordinate the rights and duties between foreign investors and the host state, with both parties enjoying unequal social powers and considering the contributory liabilities of the officials of the host state in joint corrupt misconduct when deciding the penalties for foreign investors should never mean "capitulating to investors.", Second, following the principle of "no one is to be punished twice for one offense," the number of economic losses awarded in anterior ICSID arbitration on the part of foreign investors can reasonably offset the final monetary penalties imposed by domestic anti-corruption authorities. 
Situation Two: Domestic Anti-corruption Investigation Preceding ICSID Arbitration When an investigation conducted by domestic anti-corruption authorities reveals that an investor has corruptly procured an investment contract, the corrupt misbehavior creates a perverse incentive for the host state to expropriate the investor's assets by offering the state immunity from claims. However, host states might attempt to renegotiate the investment contract to insert burdensome new terms, secure in the knowledge that they are protected by the corruption defense.

- Opportunity for Cure

When a foreign investor is involved in corruption during an investment, one plausible solution would be to mandate an opportunity for the investor to solve its breach of the investment contract. In this case, the investor should make a payment to compensate the host state for all the actual damages incurred by the investor's corruption. Once the compensation is paid, the host state should then relinquish any claim to the corruption defense upon payment of damages to the host state for all actual harm incurred because of the corruption. ${ }^{76}$

Practically, however, the actual injury resulting from bribery might be difficult to assess. If no actual damages can be calculated, an alternative could be the payment of nominal damages or a contribution to an anti-corruption fund in the host state.

Cure provisions can be adopted by amending existing BITs. However, it is more difficult to revise investment treaties. Therefore, individual investors could negotiate cure provisions into their investment contracts. The main advantage of such provisions is that they would negate the incentives of host states to expropriate, thereby ensuring that the investors retain access to a neutral forum for protecting their assets and unscrupulous host states do not benefit from their own wrongdoing.

- Disclosing the Details of Domestic Anti-corruption Enforcement Actions upon the Request of ICSID Tribunals

In practice, aimed at keeping with the principle of restitutio in integrum and the doctrine of "unclean hands," before the domestic anti-corruption investigation 
begins, the American anti-corruption authorities usually sign a prosecution agreement with the investor in which the latter is required to agree not to bring an ICSID claim against the host state for any expropriation that has already occurred. ${ }^{78}$ Domestic authorities could take this obligation by threatening to release evidence to the arbitral tribunal if the investor does bring such a claim. Although such an approach might prevent host states from utilizing domestic anti-corruption enforcement actions as signals to expropriate, it would introduce further opacity into the application of the domestic anti-corruption legislation, which might not be thus desirable. Therefore, when the result of the anti-corruption is shown (especially for a positive result), the expropriation action of the foreign investment by the host state becomes a natural thing.

Because everyone can be a target to be penalized for corrupt activities, however, the fortune of foreign investors can be described as "life floating and sinking as duckweed," while international investment arbitration becomes the main "lifesaving" mechanism for investors. Regarding the situation of "Domestic Anticorruption Investigation Preceding ICSID Arbitration," anti-corruption authorities could refuse to share any evidence with an ICSID tribunal. Such an approach might be suspicious of utilization by the host states of domestic anti-corruption enforcement actions as instruments to expropriate investor assets.

In addition, it would introduce further opacity to the future operation of domestic anti-corruption enforcement. Therefore, strengthening the interaction and counterbalance between the domestic anti-corruption enforcement mechanism and ICSID arbitration proceedings is a critical issue that urgently needs to be solved in international investment arbitration research and practice.

Fortunately, with China's pioneering efforts to promulgate and implement the International Criminal Judicial Assistance Law of the People's Republic of China (2018), the legal barriers of mutual assistance in such activities as criminal inquiry, investigation, prosecution, trial, and execution between the Chinese government and international organizations (such as ICSID) have been successfully removed. ${ }^{79}$ The general rules of international criminal judicial assistance embodied in Chapters 2-6. 
Situation Three: Simultaneous Proceedings between ICSID Arbitration and Domestic Anti-corruption Enforcements

Although ICSID tribunals have the legal power to command or compel the disputing parties to submit evidence and documents, this power is different from the investigatory power vested in the domestic anti-corruption authorities (such as DOJ, SEC, and the FBI under the FCPA in the US). The clues regarding the corruption of foreign investors are more easily noticed or more effectively controlled by investors' home or host states and the domestic anti-corruption authorities responsible for investigations and enforcement have clear advantages in evidence collection and site investigating. This becomes one of the reasons why ICSID tribunals are recommended to wait for the results of domestic investigations.

- ICSID Tribunals to Suspend the Arbitral Proceedings

In the US, the FBI can uncover evidence that may entirely escape the notice of an arbitral tribunal. To benefit from the investigative resources of the bodies tasked with anti-corruption enforcement, ICSID tribunals should make it their policy to ask for recommendations about whether to stay proceedings pending an FCPA outcome. ${ }^{80}$ In addition, investors are encouraged to stay ICSID claims pending the results of FCPA investigations to ensure the correct arbitral awards are granted. By doing so, it allows domestic anti-corruption authorities to conduct full investigations whose results can help inform the outcome of the ICSID claim. ${ }^{81}$

In practice, however, ICSID tribunals may be reluctant to wait for the outcome even when an anti-corruption investigation of an investor's misconduct is still in process. For example, the Fraport tribunal refused to grant a stay requested by the respondent host state during arbitral proceeding. ${ }^{82}$ The Fraport case indicates that it will never be an easy job to make future tribunals accept the stay claims raised by the disputing parties. ${ }^{83}$ As far as the arbitration efficiency is concerned, tribunals should be more willing to grant a stay requested by the claimant because the claimant could ultimately decide whether to drop or proceed with its claim. In addition, not to follow in the step of the Siemens case, future ICSID tribunals should be especially eager to collect as much information from domestic anticorruption proceedings as possible to assure that they render the correct awards. 
- The Bridging between Domestic Anti-corruption Investigation and ICSID Arbitration

ICSID arbitral proceedings could resume after a domestic anti-corruption investigation concludes. Depending on the outcome of the investigation, domestic anti-corruption enforcement authorities may take different steps to cooperate with ICSID tribunals. If a domestic authority investigation uncovers no evidence of corruption, the authority could convey to the investment arbitration tribunal that nothing was found. On the contrary, when an investigation does uncover evidence of corruption, the domestic authority may not hesitate to share that evidence with an ICSID tribunal and the tribunal should reach correct decisions regarding its impartiality and neutrality. ${ }^{84}$

Therefore, ICSID tribunals could gladly enlist domestic anti-corruption authorities as 'detectives' to ensure that an award is rendered based on accurate and complete facts. Meanwhile, domestic authorities should willingly offer their assistance because ICSID awards based on correct information will reward honest investors, while punishing corrupt ones, which are the international liabilities shared by domestic anti-corruption enforcement authorities. ${ }^{85}$

\section{Conclusion}

When confronted with foreign investors' ICSID arbitration claims, the host state spares no effort in asserting its exemption from legal liabilities. Thus, the corruption defense is more frequently employed by the host state in investment arbitration to frustrate claims by investors. Corruption issues attract greater attention in ICSID arbitration practice and sometimes even evolve into the critical or focal point during an arbitral trial. While deciding on corruption-involved international investment cases, some ICSID tribunals have concluded their lack of jurisdiction even during the preliminary jurisdictional stage without conducting following substantive examinations of the disputes: (1) the decline by the ICSID tribunal is suspicious of infringing procedural justice; (2) there exist uncertainties of examining the in accordance requirement during the investment process and arbitration practice; (3) the tribunals' declining of jurisdiction incurs a substantial imbalance of interests between the disputing parties, and so on. Such arbitral 
jurisprudence is readily subject to strong criticism. To overcome such flaws in ICSID arbitration, ICSID tribunals should lawfully exercise their jurisdiction and probe into the nature of corrupt activities. Tribunals should adopt the balancing approach in deciding the cases and weigh up fairly the obligations, rights, and interests among the disputing parties. It is strongly proposed to strengthen the collaborative interaction between ICSID proceedings and the domestic enforcement mechanism to combat against corrupt activities in international investments.

\section{REFERENCES}

1. T. Morchiladze, Impact of Investment Wrongdoing on Arbitration Proceedings: How Far Should an Investment Wrongdoing Get? (2012) (LL.M. dissertation, University of Oslo) (on file with author), available at https://www.duo.uio.no/handle/10852/35644.

2. The earliest ICSID investment case in which one disputing party raised corruption defense is the Wena v. Egypt case. However, the arbitral tribunal eventually decided that the corruption issue in the case had nothing to do with international investment law. See Wena Hotels Ltd. v. Arab Republic of Egypt, ICSID Case No. ARB/98/4, Decision on the Application by Wena Hotels Ltd. for Interpretation of the Arbitral Award, ๆ 46 (Oct. 31, 2005).

3. SGS Société Générale de Surveillance S.A. v. Islamic Republic of Pakistan, ICSID Case No. ARB/01/13, Decision on the Tribunal on Objections to Jurisdiction, q1 141-143 (Aug. 6, 2003).

4. ICSID tribunals generally hold that the evidentiary burden is placed upon the host state for asserting the defense. See M. Losco, Streamlining the Corruption Defense: A Proposed Framework for FCPA-ICSID Interaction, 63 Duke L. J. 1203 (2014). Although the uniform testifying criterion applicable to all the ICSID tribunals is not yet certain, it is supposedly to adopt a relatively higher standard. But one Chinese scholar points out that the traditional reason and potential motivation for international commercial arbitral tribunal to adopt the "higher testifying criterion" does not exist in international investment arbitration. See Hailang Wang, On the Testifying Criterion of Bribery in International Investment Arbitration [论国际投资仲裁中贿赂行为的证明标准], 1 L. ScI. [法律科学] 158-67 (2012).

5. Inceysa Vallisoletana, S.L. v. Republic of El Salvador, ICSID Case No. ARB/03/26, Award, ๆ 53 (Aug. 2, 2006). 
6. World Duty Free Company Limited. v. Republic of Kenya, ICSID Case No. ARB/00/7, Award, ๆ 161 (Oct. 4, 2006).

7. Id. at 9157.

8. Losco, supra note 4, at 1223.

9. China-India BIT (2006) art. 1(b). It provides: “ 'investment' means every kind of asset established or acquired, including changes in the form of such investment, in accordance with the national laws of the Contracting Party in whose territory the investment is made and in particular, though not exclusively ..."

10. J. Hepburn, In Accordance with Which Host State Laws? Restoring the 'Defence' of Investor Illegality in Investment Arbitration, 5 J. InT'L Disp. Settlement 531-59 (2014).

11. World Duty Free, supra note 6. In the below cases, the tribunals decided to decline the jurisdiction over the disputes. See Fraport AG Frankfurt Airport Services Worldwide v. The Republic of the Philippines, ICSID Case No. ARB/03/25, Decision on the Application for Annulment of Fraport AG Frankfurt Airport Services Worldwide, (Dec. 23, 2010); Inceysa Vallisoletana, S.L. v. Republic of El Salvador, ICSID Case No. ARB/03/26, Award, (Aug. 2, 2006); Metal-Tech Ltd. v. The Republic of Uzbekistan, ICSID Case No. ARB/10/3, Award, (Oct. 4, 2013); MOL Hungarian Oil and Gas Company Plc. v. Republic of Croatia, ICSID Case No. ARB/12/32, Decision on Respondent's Application Under ICSID Arbitration Rule 41(5), (Dec. 2, 2014).

12. Supra note 5, at 983.

13. Losco, supra note 4, at 1201-41. See also M. Halpern, Corruption as a Complete Defense in Investment Arbitration or Part of a Balance, 23:2 Willamette J. Int'L L. \& Disp. Res. 297-312 (2016); M. Habazin, Investor Corruption as a Defense Strategy of Host States in International Investment Arbitration: Investors' Corrupt Acts Give an Unfair Advantage to Host States in Investment Arbitration, 18 Cardozo J. Conflict Resol. 805-26 (2017).

14. A. Kulick, Global Public Interest in International Investment Law 314 (2012).

15. Metal-Tech Ltd., supra note 11, at 9110.

16. Supra note 5 , at 9245.

17. Biwater Gauff (Tanzania) Ltd. v. United Republic of Tanzania, ICSID Case No. ARB/05/22, Award, (July. 24, 2008), at $₫ 310$.

18. China-Germany BIT, art. 1. It provides: "For the purpose of this Agreement: 1. The term "investment" means assets as permitted by each Contracting Party according to its respective laws and regulations and includes mainly: ..."

19. China-Uganda BIT, art. 1. It provides: "For the purpose of this Agreement 1. the term "investment" means every kind of asset invested directly or indirectly by investors of one Contracting Party in the territory of the other Contracting Party, and in particular, though not exclusively, includes: ..."

20. Hongwu Yin, The Evolution of Chinese Bilateral Treaties-The Multilateralization OF International InVEstment LaW as The Setting [中国双边投资条约的演进-以国际投资 
法趋同化为背景] 105 (2017).

21. Losco, supra note 4, at 1201-41.

22. Fraport AG Frankfurt Airport Services Worldwide, supra note 11, at $₫ 345$.

23. Id. at 396. (listing several arguments in favor of a liberal policy of granting jurisdiction to investors' claims).

24. Id. at 9346.

25. The World Duty Free tribunal did not attribute the then president's bribe-taking to host government and declined the "estoppels" assertion raised by foreign investor accordingly. See World Duty Free, supra note 6, at 9183 . Hence, some scholars show concerns that if future tribunals continue to adhere to the same arbitral jurisprudence, the "estoppels" cause will rarely be asserted. See J. Yackee, Investment Treaties and Investor Corruption: An Emergent Defense for Host States?, 52 VA. J. InT'L L. 741-2 (2012); World Duty Free, supra note 6, at 9183.

26. Losco, supra note 4, 1201-41.

27. Habazin, supra note 13 , at 816.

28. The author refers to ICSID tribunals which prefer to decline the jurisdiction over foreign investment "tainted" by corruption. Confronting similar questions, several tribunals have affirmed his premise that corrupt contracts are void as contrary to international public policy. See supra note 5, at 252; World Duty Free, supra note 6, at 157.

29. Supra note 14, at 456.

30. Convention on the Settlement of Investment Disputes between States and Nationals of Other States, art. 27(1), Oct. 14, 1966, 575 U.N.T.S. 159. It provides: “(1) No Contracting State shall give diplomatic protection, or bring an international claim, in respect of a dispute which one of its nationals and another Contracting State shall have consented to submit or shall have submitted to arbitration under this Convention, unless such other Contracting State shall have failed to abide by and comply with the award rendered in such dispute."

31. Habazin, supra note 13, at 805-28.

32. Losco, supra note 4, at 1201-41.

33. Supra note 14 , at 123.

34. T. Meshel, The Use and Misuse of the Corruption Defence in International Investment Arbitration, 30 J. INT'L ARB. 274 (2013).

35. Siemens A.G. v. The Argentine Republic, ICSID Case No. ARB/02/8, Award, (Feb. 6, 2007), at 978.

36. A. Kulick \& C. Wendler, A Corrupt Way To Handle Corruption?: Thoughts on the Recent ICSID Case Law on Corruption, 37:1 Legal Issues ECon. INTEGRATION 61-85 (2010).

37. Id. at 83 .

38. The phrase "building a community with a shared future for mankind", a concept constantly mentioned by President Xi Jinping both at home and abroad, not only shows 
China's wisdom in global governance, but also its determination to work for an equal, open and peaceful world. Xi reiterated such vision and commitment on the world stage in his many state visit remarks. See Yao Lan, Xi calls for building SCO community with a shared future, XINHUANET, June 10, 2018, available at http://www.ecns.cn/ news/politics/2018-06-10/detail-ifyuyvzv3227139.shtml. In the author's viewpoint, the construction of a "clean and beautiful" international investment community is the indispensable part of building "A Common Community for Mankind with a Shared Future."

39. Supra note 14 , at 86 .

40. Convention on Combating Bribery of Foreign Public Officials in International Business Transactions, art. 1.

41. Wena Hotels Ltd., supra note 2, at $9 \uparrow 111-112$ \& 132.

42. J.W. Yackee, Investment Treaties and Investor Corruption: An Emergent Defense for Host States?, 52 VA. J. InTL. L. 741-2 (2012).

43. Fraport AG Frankfurt Airport Services Worldwide, supra note 11, at qศ 401-406; Inceysa, supra note 11, at ๆๆ 250-252; Plama Consortium Limited v. Republic of Bulgaria, ICSID Case No. ARB/03/24, Award, (Aug. 27, 2008), at 9 321; World Duty Free, supra note 6, at 157.

44. Inceysa, supra note 11, at 202.

45. Tokios Tokelès v. Ukraine, ICSID Case No. ARB/02/18, Award, (July 26, 2007), at 93.

46. Supra note 14 , at 332-6.

47. Halpern, supra note 13, at 297-317.

48. Id. at 314 .

49. B. Greenwald, The Viability of Corruption Defenses in Investment Arbitration When the State Does Not Prosecute, Eur. J. InT'L L. Blog. (Apr. 15, 2015), available at https:// www.ejiltalk.org/the-viability-of-corruption-defenses-in-investment-arbitration-whenthe-state-does-not-prosecute/.

50. T. Sinlapapiromsuk, The Legal Consequences of Investor Corruption in Investor-State Disputes: How Should the System Proceed?, 3 Transnat'l Disp. Mgmt. 33 (2013).

51. R. Torres-Fowler, Undermining ICSID: How the Global Antibribery Regime Impairs Investor-State Arbitration, 52 VA. J. INT'L L. 1029-30 (2012).

52. Supra note 10, at 534.

53. Draft Articles on Responsibility of States for Internationally Wrongful Acts, art. 4. It provides: "1. The conduct of any State organ shall be considered an act of that State under international law, whether the organ exercises legislative, executive, judicial or any other functions, whatever position it holds in the organization of the State, and whatever its character as an organ of the central government or of a territorial unit of the State."

54. Supra note 10 , at 543.

55. Supra note 1. 
56. Losco, supra note 4, at 1220.

57. Supra note 36 , at 83.

58. Losco, supra note 4, at 1231-2.

59. R. Torres-Fowler, Undermining ICSID: How the Global Antibribery Regime Impairs Investor-State Arbitration, 52 VA. J. INT'L L. 1029-30 (2012).

60. OECD Convention Combating Bribery, art. 1(1). It defines "bribery" mainly referring to "bribe-offering", not covering "bribe-taking."

61. The practice proves that the OECD Convention's influence is quite limited in the context of international investment arbitration. Therefore, the significance of the OECD Convention is better to be said that it transmits a signal to the international community: "the corruption problem which international public policy concerns should be drawn increasing attention and be addressed in various ways."

62. USMCA Agreement art. 27.9, available at https://ustr.gov/trade-agreements/free-tradeagreements/united-states-mexico-canada-agreement. It provides: "Cooperation 4. The Parties acknowledge the importance of cooperation and coordination internationally, including the OECD Working Group on Bribery in International Business Transactions, the UNCAC Conference of the State Parties and the Mechanism for Follow-Up on the Implementation of the IACAC, as well as their support to the APEC Anti-Corruption and Transparency Working Group and the G20 Anti-Corruption Working Group."

63. International Criminal Judicial Assistance Law [中华人民共和国国际刑事司法协助法] (Presidential Decree No. 13, Oct. 26, 2018).

64. Id. art. 1.

65. "Which" in the sentence refers to the "legally interactive mechanism," not "ICSID."

66. Siemens, supra note 35.

67. Supra note 59, at 1027.

68. Losco, supra note 4, at 1235.

69. World Duty Free, supra note 6, at $9164 \& 186$.

70. Losco, supra note 4, at 1234.

71. Id. at 1235 .

72. R. Bhojwani, Deterring Global Bribery: Where Public and Private Enforcement Collide, 112 Colum. L. Rev. 66 (2012).

73. Losco, supra note 4, at 1235-6.

74. Id.

75. Id. at 1236.

76. Losco, supra note 4, at 1238.

77. Id.

78. Id. at 1239 .

79. International Criminal Judicial Assistance Law, art. 67. It provides: “The People's Republic of China and relevant international organizations that carry out criminal judicial 
assistance shall be governed mutatis mutandis to the provisions of this Law."

80. Losco, supra note 4, at 1240.

81. Such fact-finding could potentially be a costly endeavor. Any costs arising from expediting an investigation or producing evidence to a tribunal could be borne by the parties to the ICSID dispute. See id.

82. Fraport AG Frankfurt Airport Services Worldwide, supra note 11, at $\uparrow \uparrow$ 5, $27 \& 47$.

83. Id. at 47 (explaining the tribunal's denial of the stay request and its perception that the record was sufficient).

84. D. Weiss, The Foreign Corrupt Practices Act, Sec Disgorgement of Profits, and the Evolving International Bribery Regime: Weighing Proportionality, Retribution, and Deterrence, 30:2 Мich. J. InT'L L. 511-2 (2009).

85. Losco, supra note 4, at 1240. 